\title{
Présentation du numéro
}

\section{Introduction to this issue}

\section{Julia COHEN-LÉVY}

Rédacteur en chef du numéro

Chief editor of this issue

\section{FOREWORD}

\section{Adresse}

de correspondance :

J. COHEN-LÉVY,

255, rue Saint-Honoré

75001 Paris.
L'année 2008 commence par un numéro varia ambitieux, qui a souhaité aborder de nombreuses facettes de notre discipline. Dépistage, thérapeutique fonctionnelle, orthopédique, finitions occlusales, recherche fondamentale... des pages qui se suivent, se complètent sans se ressembler.

La thérapeutique a la part belle, dans ses aspects les plus variés.

Qui n'est pas resté perplexe en fin de traitement multiattache devant la difficulté d'obtenir simultanément des relations de classe I au niveau canin et molaire ? Avec la question de la dysharmonie dento-dentaire postérieure, abordée de façon très intéressante par Oueiss et $a l$., cette question ne devrait pas rester sans réponse.

L'orthopédie des malocclusions de classe II est représentée par des articles originaux, proposant des variations sur le thème de la force extra-orale et des propulseurs mandibulaires :

Fort d'une longue expérience clinique sur les bielles de Herbst, Michel Amoric en développe les possibles adaptations, notamment le décolletage des gouttières. Un peu plus loin, Peyrolade et al. nous proposent une étude céphalométrique sur l'arc facial avec equi-plan pour les mal-
We begin the year 2008 with an ambitions varia issue in which we present a number of aspects of our profession. Detection of anomalies, functional therapies, orthopedics, occlusal finishing, and basic research... the pages that unfold from this point forward complete our thoughts without closely resembling each other.

Therapeutics takes a leading position in all of its manifold varieties. Which of us has not been lost in perplexity at the close of a full-banded treatment in a fruitless effort to achieve simultaneous Class I relationships of both cuspids and molars? And to the question of posterior arch length discrepancy, elucidated in a highly interesting fashion by Oueiss and colleagues, responses will certainly be forthcoming.

In original articles, contributing authors propose variations on the theme of orthopedic treatment of Class II malocclusions with extra-oral force and mandibular advancement appliances:

Armed with vast clinical experience with the Herbst appliance, Michel Amoric has conceived of possible adaptations in its use, notably with uncovering of splints. A little further on in this tome, Peyrolade, et al. present a cephalometric 
occlusions associant un fort décalage sagittal et un excès de recouvrement.

Mais la mécanique n'est pas tout... C. Boucher et al. nous offrent ainsi les résultats d'une étude prospective sur la rééducation myofonctionnelle à l'aide d'une gouttière de type «Trainer» après disjonction maxillaire chez des patients en classe II squelettique.

$\mathrm{Si}$ les études cliniques sont importantes, les aspects fondamentaux de notre discipline le sont tout autant. Quelle est la réponse cellulaire à nos appareils orthopédiques ? Quelles sont les cascades moléculaires mises en jeu par nos dispositifs de propulsion mandibulaire sur le condyle? La revue d'ODF vous propose un article de synthèse sur le remodelage adaptatif du cartilage condylien (traduction d'un article de Shen et al., publié dans le Journal of Dental Research), à la lumière des travaux récents sur les facteurs de croissance.

Notre rôle de dépistage, particulièrement important, est abordé par l'exposé de deux cas où la découverte d'anomalies a été fortuite. Le spina bifida, anomalie rare de la charnière cranio-rachidienne, est ainsi détaillé par Vernex-Boukerma, qui nous invitent à le rechercher sur les téléradiographies de profil. Un cas clinique suivi pendant près de 7 années est illustré dans la rubrique radiographique (Bahije et al) pour ne pas écarter la possibilité d'un retard de minéralisation plutôt qu'une agénésie...

... enfin ce numéro ne saurait être complet sans la touche culturelle apportée par J. Philippe, qui retrace pour nous la naissance de l'edgewise.

Merci à tous ces auteurs pour la richesse de ce numéro...varia donc. study on results achieved with a face bow and anterior bite plate in cases with serious sagittal discrepancies and deep anterior overbite. But mechanics are not everything... C. Boucher et al offer for our instruction the results of a prospective study on myofunctional therapy associated with the wearing of a "Trainer" appliance after rapid palatal expansion for patients with Class II skeletal malocclusions.

While clinical studies are certainly important, the fundamental aspects of our discipline are equally critical. What is the cellular response to the orthopedic forces we employ? What molecular cascades in the region of the condyles do we set off with our mandibular advancement devices? This ODF journal gives you a chance to inspect a basic research article on adaptive remodeling of condylar cartilage examined in the light of the latest research in growth factors that is a translation of an essay by Shen et al originally published in the Journal of Dental Research.

Our role in the highly important enterprise of early detection of disease is discussed through the presentation of two cases where anomalies were discovered by chance. VernexBoukerma invites us all to follow a research study of spina bifida, a rare disorder in the cranio-rachidienne framework, undertaken with profile cephalograms. And Bahije et al, through a case illustrated radiographically over a 7 year period remind us not to ignore the possibility that delayed calcification, not agenesis, may be at the root of certain perplexing problems.

and, finally, this issue would be sadly incomplete without the cultural historical touch that J. Philippe brings to it as he outlines the history of the birth of the edgewise appliance.

A warm thank you to all the authors who have contributed to the truly varia richness of this issue. 